\title{
A jelentési és tanulórendszerek szerepe a betegbiztonság javításában
}

\author{
Lám Judit dr. ${ }^{1}$ - Sümegi Viktória dr. ${ }^{2}$ - Surján Cecília ${ }^{1}$ \\ Kullmann Lajos dr. ${ }^{3}$. Belicza Éva dr. ${ }^{1}$ \\ ${ }^{1}$ Semmelweis Egyetem, Egészségügyi Menedzserképző Központ, Budapest \\ ${ }^{2}$ Szegedi Tudományegyetem, Általános Orvostudományi Kar, Szent-Györgyi Albert Klinikai Központ, Szeged \\ ${ }^{3}$ Eötvös Loránd Tudományegyetem, Bárczi Gusztáv Gyógypedagógia Kar, Budapest
}

\begin{abstract}
Az Egészségügyi Világszervezet nemkívánatos események jelentési és tanulórendszereivel foglalkozó, 2005-ben megjelent irányelve fektette le a betegbiztonsággal foglalkozó jelentési rendszerek kialakításának alapelveit. Mára Magyarországon is egyre több egészségügyi intézményben jelentkezik igény a betegbiztonsági szemlélet és szervezeti kultúra kialakítására. Ebben nyújt segítséget a 2006-ban elindult és a megújult NEVES (NEm Várt ESemények) elnevezésű jelentési és tanulórendszer, valamint a hozzá kapcsolódó Betegbiztonsági Fórum továbbképző és konzultációs sorozat. A program bemutatásának aktualitását az egészségügyi törvény 2016. január 1-jétől hatályos, a betegbiztonság javítását is elváró módosítása adja. Orv. Hetil., 2016, 157(26), 1035-1042.
\end{abstract}

Kulcsszavak: betegbiztonság, jelentési és tanulórendszerek, nemkívánatos események

\section{Role of reporting and learning systems in the improvement of patient safety}

The principles and requirements of a patient safety related reporting and learning system were defined by the World Health Organization Draft Guidelines for Adverse Event Reporting and Learning Systems published in 2005. Since then more and more Hungarian health care organizations aim to improve their patient safety culture. In order to support this goal the NEVES reporting and learning system and the series of Patient Safety Forums for training and consultation were launched in 2006 and significantly renewed recently. Current operative modifications to the Health Law emphasize patient safety, making the introduction of these programs once again necessary.

Keywords: patient safety, reporting and learning systems, adverse events

Lám, J., Sümegi, V., Surján, C., Kullmann, L., Belicza, É. [Role of reporting and learning systems in the improvement of patient safety]. Orv. Hetil., 2016, 157(26), 1035-1042.

(Beérkezett: 2016. február 28.; elfogadva: 2016. április 8.)

\section{Rövidítések}

BELLA = BetegELLátók Akkreditációja; NEKED = Nemkívánatos Események Kezelésére vonatkozó EljárásrenD; NEVES = NEm Várt ESemények

$\mathrm{Az}$ ismert adatok szerint minden 10. beteg egészségügyi ellátása során előfordul olyan nemkívánatos esemény (1. táblázat), amely az ellátáshoz köthető bántalom és nem a beteg állapotából, betegségéből adódó szövődmény $[1,2]$. A nemkívánatos események jelentős következményekkel járnak mind a beteg és hozzátartozói, mind az érintett ellátásban részt vevő egészségügyi személyzet, az egészségügyi szolgáltató és az egészségügyi rendszer szintjén is, hiszen a pszichés következmények mellett számolni kell az ellátás eredményességének és hatékonyságának romlásával egyaránt. A közlemények szerint ugyanakkor a nemkívánatos események 70\%-a megfelelő intézkedésekkel megelőzhetővé tehető $[1,3]$. A 2000-es évek elejétől elinduló betegbiztonsági kutatások arra a fó kérdésre keresik a választ, hogy hogyan védhetők meg a betegek és az őket ellátók az ellátási, gondozási tevékenység során kialakuló nemkívánatos eseményektől, akaratlan bántalmaktól. 
A nemkívánatos események hátterében 85-90\%-ban a kapcsolódó folyamatok gyengeségei játszanak szerepet, és mindössze 10-15\%-ban azonosítható kizárólag az ellátók egyszemélyi felelőssége [3]. A kutatások tanulságai szerint, bár minden előforduló nemkívánatos esemény egyedi, az előfordulás földrajzi helyétől függetlenül a hasonló típusú nemkívánatos események hátterében hasonló okok és hozzájáruló tényezők azonosíthatók [2]. A háttérben álló okok szisztematikus elemzésen alapuló megismerésével, a feltárt tényezőkre ható megelőző intézkedések meghozatalával a nemkívánatos események előfordulása csökkenthető, így az egészségügyi ellátás biztonságosabbá válik mind a beteg, mind az ellátó számára.

A nemkívánatos események hátterében álló okok és mintázatok feltárását a megfelelő feltételek mentén kialakított jelentési rendszerek segíthetik. Az előforduló nemkívánatos események jelentése, gyưjtése és megfelelő értékelése nélkül a hátterükben álló okok, kiváltó tényezők sokáig ismeretlenek maradhatnak. Ez korlátozza a megelőzést szolgáló intézkedések meghozatalának lehetőségét és ezzel előfordulásuk csökkentését.

A közlemény célja, hogy bemutassa a jelentési és tanulórendszerek szerepét a betegbiztonság javításában, és ismertesse az e feladatot ellátó hazai NEVES (NEm Várt ESemények) programot. A közlemény aktualitása az egészségügyi törvény 2016. január 1-jén hatályba lépett módosítása, amely megfogalmazza az egészségügyi szolgáltatók felé a nemkívánatos eseményekből való tanulás elvárását. A jogszabály nem várja el a NEVES rendszer használatát, de mivel az eszköz regisztrációt követően szabadon hozzáférhető és a tanulást támogató fórumok is ingyen látogathatók, dolgozatunkkal szeretnénk hozzájárulni a rendszer megismertetéséhez és minél szélesebb körű alkalmazásához.

1. táblázat |Alkalmazott fogalmak és meghatározásuk

\begin{tabular}{ll}
\hline Fogalom & Meghatározás \\
\hline Nemkívánatos esemény & $\begin{array}{l}\text { Az ellátás nyújtásához köthető, } \\
\text { az elvégzett vagy elmaradt tevékenység } \\
\text { következtében fellépó betegkárosodás } \\
\text { és nem a betegségból eredő komplikáció. }\end{array}$ \\
\hline $\begin{array}{l}\text { Egészségügyi } \\
\text { szolgáltatók } \\
\text { akkreditációja }\end{array}$ & $\begin{array}{l}\text { Az adott ellátási formára specifikus } \\
\text { standardok szerinti múködés elismerése, } \\
\text { amely az egészségügyi szolgáltatók } \\
\text { önértékelésén és külső kollegiális } \\
\text { felülvizsgálatán keresztül valósul meg. }\end{array}$ \\
\hline Akkreditációs standard & $\begin{array}{l}\text { Az egészségügyi szolgáltató betegellátással } \\
\text { kapcsolatos, napi múködését leíró } \\
\text { szabályozó. }\end{array}$ \\
\hline Gyökérok & $\begin{array}{l}\text { A gyökérok(ok) a legalapvetőbb } \\
\text { faktor(ok), amely(ek) korrekciója vagy } \\
\text { kiiktatása egy szituáció vagy hiba } \\
\text { előfordulását mérsékli [12]. }\end{array}$ \\
\hline
\end{tabular}

\section{A nemkívánatos események lényege}

A nemkívánatos események olyan, az ellátott beteget érő károsodásokat jelentenek, amelyek az ellátás nyújtása, késése vagy elmaradása következtében jönnek létre. Az ellátás minden szintjén és formájában előfordulhatnak. A legfontosabbak között említhetők az egészségügyi ellátással összefüggő fertőzések, helytelen gyógyszeralkalmazás miatti egészségi állapot-, életminőség-romlás, fizikai sérülések, késés a gyógyulásban, nem a betegségből eredő állapotromlás vagy halálozás. A nemkívánatos események hátterében leggyakrabban a mikrorendszerek, a szakmai és a múködési folyamatok tervezési gyengeségei és az ellátói környezetből adódó befolyásoló tényezők által kiváltott végrehajtási hibák állnak [1].

\section{Nemzetközi és hazai ajánlások és szabályozók a jelentési rendszerek alkalmazására vonatkozóan}

A nemkívánatos események jelentési és tanulórendszereinek kialakításával kapcsolatos alapokat az Egészségügyi Világszervezet (WHO) 2005. évi irányelve fektette le a mai napig érvényes kulcsüzenetek megfogalmazásával [4].

2009-ben jelent meg az EU Tanácsának 2009/C 151/01 számú ajánlása az egészségügyi ellátással összefüggő fertőzések megelőzését és leküzdését is magában foglaló betegbiztonságról. Ez támogatni és erősíteni kívánja a tagállamok által múködtetett, anonim és szankciómentes jelentési és tanulórendszereket. Az ajánlás teljesítésének állásáról valamennyi tagállamnak, így hazánknak is rendszeres beszámolási kötelezettsége van [5].

A nemzetközi ajánlások és szabályozók mellett a nemkívánatos események jelentési rendszerére vonatkozóan hazai jogszabályi elvárásokat és egyéb szabályozókat is megfogalmaztak.

A nemkívánatos események körébe sorolható, egészségügyi ellátással összefüggő fertőzések és a farmakovigilanciához kapcsolódó gyógyszereléssel összefüggő, megelőzhető nemkívánatos események jelentését is jogszabályok írják elő $[6,7]$. Megjegyezzük, hogy ezeknek a jelentéseknek a célja fóként a statisztikai adatgyújtés, mélyebb oki elemzésre nem alkalmasak.

A magyar fejlesztésú, a betegellátás biztonságának javítását célzó BELLA (BetegELLátók Akkreditációja a biztonságos betegellátásért) akkreditációs rendszer alapját képező standardok (1. táblázat) elvárásként fogalmazzák meg az intézmények számára a jelentési rendszerek múködtetését és a jelentésekből való tanulást támogató szervezeti kultúra megteremtésére való törekvést. Az így múködtetett jelentési rendszerekból származó adatok felhasználandók a szervezet minőségfejlesztési törekvéseinek meghatározásában, a folyamatok fejlesztésében, az így azonosított veszélyek tudatos kezelésében. 
Az egészségügyi szolgáltatók akkreditációját lehetővé tevő jogszabályi hátteret az egészségügyi törvény biztosítja. Míg a törvény alapján a szolgáltatók akkreditációra való jelentkezése önkéntes, addig a jogszabály szerint minden egészségügyi szolgáltatónak belső minőségügyi rendszert kell múködtetnie. Az egészségügyi törvény 2016. január 1-jétől hatályos módosítása alapján a belső minőségügyi rendszer múködtetése magában foglalja többek között a „betegbiztonsággal összefüggö kockázatok, a nemkivánatos események áttekintését, elemzését, értékelését és a megelózö intézkedések megfogalmazását” is. A jogszabályi elvárás teljesítésének feltétele és eszköze a belső jelentési rendszerek bevezetése és múködtetése [8].

\section{A szervezeti tanulás és jelentési rendszerek kapcsolata}

A nemkívánatos események jelentésére alkalmas rendszerek legfontosabb célja a betegbiztonság javítása az összegyưlt adatok elemzésének segítségével. Az eredmények hasznosulásának több szintje is lehetséges (1. ábra) [9].

A rendszerhez csatlakozó ellátók számára a saját jelentésekből származó adatok elemzésével lehetővé válik azon belső, szervezeti szintű okok feltárása, amelyek a nemkívánatos események hátterében állnak, így intézményspecifikus válaszokat fogalmazhatnak meg a továb- bi, hasonló események előfordulásának csökkentése, elkerülése érdekében.

Az intézményi szintû okok megismerésén túl fontos tanulási forrás lehet az országos adatok elemzése. Ez lehetővé teszi az általános szervezeti és az ellátórendszer szintjén jelen levő okok feltárását is. Az ezekre megfogalmazott megoldások publikálása, illetve standardokba ültetése valamennyi érintett intézmény számára hasznosítható eredményt hozhat. Az adott témakörben beérkezett, valamennyi jelentésre támaszkodó oki kutatások emellett rámutathatnak az intézményi szinten nem kezelhető okokra, az egészségpolitikai szintű beavatkozások szükségességére.

\section{A hazai jelentési rendszer - a NEVES program}

A NEVES (NEm Várt ESemények) néven múködő tanuló- és jelentési rendszer kialakításának célja, hogy a jelentő intézmények segítséget kapjanak az ellátási hibák, gyengeségek feltárásához és elemzéséhez, így a megfelelő tanulságok levonásával növelhetővé váljon a betegbiztonság.

A WHO Magyarországi Irodája és az Egészségügyi Minisztérium felkérésére 2006-ban indult el a WHOajánlás adaptációját célzó munka a Semmelweis Egyetem

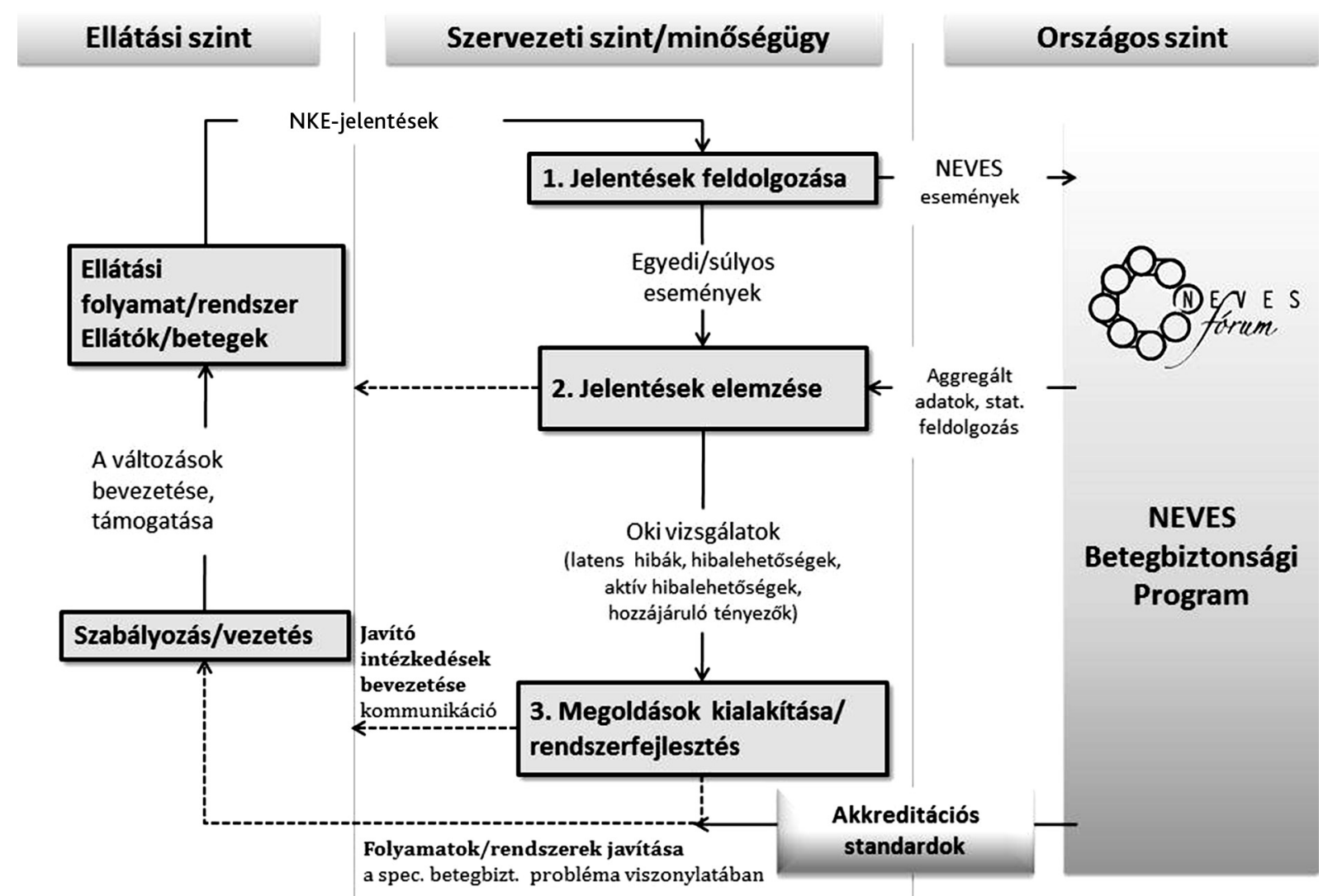

1. ábra $\quad$ A jelentések hasznosulásának lehetséges szintjei - a SAIFIR (Safety Action and Information Feedback from Incident Reporting) modell adaptációja [9] 
Egészségügyi Menedzserképző Központjában, a Magyar Kórházszövetség közremúködésével és hét kórház részvételével [10]. A fejlesztés későbbi fázisaiban a 2009-ben publikált európai uniós betegbiztonsággal kapcsolatos javaslatokat is figyelembe vettük.

A NEVES kialakításánál és a későbbi fejlesztések kapcsán is alkalmazott alapelveket a 2. táblázat foglalja össze [11]. Ennek mentén az egészségügyi szolgáltatók saját döntése, hogy melyik témában, mely osztályról küldenek jelentést, így az intézet vagy a kiválasztott osztály specialitásai figyelembe vehetők. Csak előre definiált nemkívánatos esemény jelenhető erre a célra kidolgozott adatlapon. A rendszer anonim, azaz sem az eseményhez kötődő szereplők, sem a jelentést adó intézmények nem azonosíthatók. A rendszer sajátossága, hogy oki kutatásra igen, de az események előfordulási gyakoriságának felmérésére nem alkalmas. Ez utóbbinak az a magyarázata, hogy a jelentések önkéntesek, így nem biztosítható minden előfordulás megjelenése a jelentések között, illetve nem ismert a viszonyítási alap, azaz az a populáció, amelynek körében a jelentett események előfordultak. A jelentéseket először e-mailben, később egy egyszerü informatikai eszköz segítségével on-line lehetett feladni. A feldolgozást időszakosan, manuális módszerrel végez-

2. táblázat |A NEVES jelentési rendszer jellemzői [11]

\begin{tabular}{l}
\hline Rendszerjellemzők \\
\hline Szankciómentesség \\
Anonimitás \\
Önkéntesség \\
Bizalmasság \\
Átláthatóság \\
Függetlenség a döntéshozóktól \\
Jól definiált jelentési tartalom \\
Egyszerú jelentési eljárás \\
Rendszerorientáltság \\
Szakértői elemzések végzése \\
Visszajelzés (rövid határidővel) \\
\hline
\end{tabular}

3. táblázat |Az új jelentési lapok témaválasztásának szempontjai

\begin{tabular}{l}
\hline Témaválasztás szempontjai \\
\hline Gyakran előforduló probléma \\
Járó- és fekvőbeteg-ellátásban is jelentkező probléma \\
Várhatóan magas jelentett esetszám \\
Megfelelő jelentési hajlandóság \\
Szakmai evidencia vagy irányelv foglalkozik a kérdéssel \\
Elérhető nemzetközi vagy hazai irodalom a témában \\
Jellemzóen nem súlyos végkimenetel \\
Több jól azonosítható folyamat eredménye \\
Többnyire nem egyszemélyi felelősség feltételezhető a háttérben
\end{tabular}

tük, ami sértette az alapelvek utolsó pontját: a mielőbbi visszajelzés elvárását (2. táblázat), ezért 2012-ben új szoftveres megoldás létrehozása mellett döntöttünk.

\section{$\mathrm{Az}$ informatikai felület szerepe}

A NEVES jelentési program legfontosabb céljaként a jelentések fogadását, naprakész feldolgozását és visszajelzését, valamint a saját feladott jelentések letölthetőségét fogalmaztuk meg. A program szakértői olyan alapértelmezett statisztikákat határoznak meg a felhasználók számára, amelyeket az oki kutatás támogatásában fontosnak ítélnek. Ezzel lehetővé válik, hogy az adatok értelmezéséből származó félreértések lehetőségét csökkentsük és segítsük az eredményekből való tanulást. Az egyes jelentéstípusokhoz beállított statisztikai elemzéseket automatikusan előállító szoftver lehetőséget nyújt további kereszttáblás elemzések készítésére, így minden felhasználó számára további egyedi statisztikák definiálására és lekérdezésére. Az informatikai felület naprakész adatokkal dolgozik, ezáltal a feldolgozásig és az érintettek számára történő visszajelzésig eltelő idő a felhasználó szándékán múlik. A saját feltöltött jelentéseket Excel formátumban lehet letölteni.

A nemzetközi ajánlásokkal összhangban kiemelt fontosságú a jelentésben érintettek anonimitásának a biztosítása. A szoftver biztonsági beállításai védik mind a jelentő személyt és osztályt, mind az esemény szereplőit. Senki, még a szoftvert kezelő, adminisztrátori joggal rendelkező személy sem kapcsolhatja össze az egyes eseteket az intézményekkel, mivel azokat a rendszerben véletlenszerúen generált kódok azonosítják.

\section{A jelentőlapok kidolgozásának szakmai koncepciója}

A NEVES jelentési és tanulórendszerben jelenleg már 21 jelenthető esemény közül választhatnak a felhasználók. A jelenthető események kiválasztási szempontjait a 3. táblázatban foglaltuk össze. Mivel az általunk támogatott oki kutatás az aggregált gyökérok (1. táblázat) kutatásának módszertanára épül [12], törekedtünk arra, hogy viszonylag gyakori eseményeket válasszunk. A ritkán előforduló, súlyos kimenetelü, úgynevezett rendkívüli események egyedi kivizsgálást igényelnek, amelyhez a NEKED (Nemkívánatos Események Kezelésére vonatkozó EljárásrenD) ajánlás alkalmazása javasolható [13].

A jelenthető események kiválasztásához további fontos szempont volt, hogy a folyamatokba való beavatkozás révén az esemény előfordulási gyakorisága valószínúen csökkenthető legyen. A jelentés lehetőségének megteremtését a téma fontossága és a várható jelentési hajlandóság is indokolta.

A jelentőlapok egységes szerkezetben készültek, céljuk a szisztematikus hibák feltárási lehetősége. Ehhez szakértői megbeszélések keretében felmértük az események 
mögött meghúzódó folyamatokat, rendszereket, lehetséges gyengeségeiket, a befolyásoló tényezőket és azonosítottuk a potenciális okokat. A jelentőlapok így információval szolgálnak a károsodásban érintett személy és az ellátásáért felelős szervezeti egység jellemzőiről, az esemény előfordulásával kapcsolatos legfontosabb tudnivalókról, a következményekről és a jelentést készítő személy(ek) szerinti megelőzési lehetőségekről.

A fejlesztés során igyekeztünk informatikai és felhasználói szempontokat is figyelembe venni, így az egységes szerkesztés egyben azt a célt is szolgálja, hogy a kitöltő munkatársak számára egy új adatlapban való tájékozódás ne jelentsen nehézséget. A kérdőívek többnyire a szakdolgozók számára is értelmezhető kérdéseket fogalmaznak meg, ám egyes jelentőlapok kitöltéséhez az orvos tudása, támogatása is szükséges. A fejlesztés során fontos szempont volt, hogy a jelentőlapok többsége a járóbeteg-ellátásban, illetve az egynapos ellátásban is használható legyen (4. táblázat).

A kérdőívek kidolgozását követően megfogalmaztunk szakmai kérdéseket, és ezek mentén állítottuk össze a visszajelző felületen elérhető azon statisztikai táblákat, amelyek a felhasználók számára támpontot nyújthatnak az adatok értékeléséhez.

\section{4. táblázat | Jelenthető témakörök, alkalmazhatóságuk}

\begin{tabular}{ll}
\hline Jelenthető események & \\
\hline Beteg eltünése, elkóborlása & $\mathrm{F} / \mathrm{J} / \mathrm{E}$ \\
Betegcsere & $\mathrm{F} / \mathrm{J} / \mathrm{E}$ \\
Betegesések & $\mathrm{F} / \mathrm{J} / \mathrm{E}$ \\
Decubitus & $\mathrm{F} /-$ \\
Dolgozót ért bántalmazás & $\mathrm{F} / \mathrm{J} / \mathrm{E}$ \\
Elmaradt tervezett mútétek & $\mathrm{F} / \mathrm{J} / \mathrm{E}$ \\
Fel nem használt vérkészítmények & $\mathrm{F} /-$ \\
Gyógyszereléssel kapcsolatos nem várt esemény & $\mathrm{F} / \mathrm{J} / \mathrm{E}$ \\
Húgyúti beavatkozást követő húgyúti fertőzés & $\mathrm{F} / \mathrm{J} / \mathrm{E}$ \\
Kanül/katéter asszociált fertőzések & $\mathrm{F} / \mathrm{J} / \mathrm{E}$ \\
Leletcsere & $\mathrm{F} / \mathrm{J} / \mathrm{E}$ \\
Leletkéslekedés & $\mathrm{F} / \mathrm{J} / \mathrm{E}$ \\
Mútéti beavatkozás után kialakult sebfertőzés & $\mathrm{F} / \mathrm{J} / \mathrm{E}$ \\
Mütéti szövődmények & $\mathrm{F} / \mathrm{J} / \mathrm{E}$ \\
Nem tervezett ismételt kórházi felvétel & $\mathrm{F} /-$ \\
Oldaltévesztés vagy más testrészen történt beavatkozás & $\mathrm{F} / \mathrm{J} / \mathrm{E}$ \\
Orvosi műszerek, eszközök elégtelen múködése miatt & $\mathrm{F} / \mathrm{J} / \mathrm{E}$ \\
kialakult nem várt esemény & \\
Öngyilkosság és öngyilkossági kísérlet & $\mathrm{F} / \mathrm{J} / \mathrm{E}$ \\
Tűszúrásos balesetek & $\mathrm{F} / \mathrm{J} / \mathrm{E}$ \\
Újraélesztés & $\mathrm{F} / \mathrm{J} / \mathrm{E}$ \\
Váratlan halálozás & $\mathrm{F} / \mathrm{J} / \mathrm{E}$ \\
\hline
\end{tabular}

$\mathrm{E}=$ egynapos ellátás; $\mathrm{F}$ = fekvőbeteg-ellátás; J = járóbeteg-ellátás.

\section{Megbeszélés}

A kórházi ellátással összefüggésbe hozható nemkívánatos események a betegek mintegy 10\%-ánál jelentkeznek. Valamilyen ellátási hibához köthető mintegy 70\%-uk, ezért ezek megelőzhetők lennének [1-3]. Az okok között nem egyéni felelősség, hanem 80-90\%-ban a nem megfelelő szervezeti tervezés, múködés, illetve a folyamatszabályozás gyengesége áll [2]. A betegbiztonság javításakor ezért a rendszer- és folyamatszintû okokra koncentrálva tudunk valódi eredményt elérni az egyéni felelősség keresése és az egyének büntetése helyett.

A WHO-irányelv alapján a nemkívánatos események jelentési és tanulórendszereinek alkalmazási célja a betegellátás biztonságának növelése azon keresztül, hogy feltárjuk és elemezzük az ellátás gyengeségeit és hibáit, továbbá ezek mentén hozunk megelőzést célzó intézkedéseket [4]. A hazai NEVES program fókuszában ezzel összhangban a tanulás elősegítése, a gyökérokokra vonatkozó információk megosztása, a megelőzést támogató gyakorlat megismertetése áll. A program fontos eleme az őszinteség, a bizalom, az anonimitás és a szankciómentesség biztosítása. Hangsúlyozzuk az oktatás és a múködési folyamatok fejlesztésének fontosságát, kiemelve, hogy az egyéni felelősség kutatása nem vezethet a szakmai és szervezeti szintű okok megtalálásához és eredményes megelőző intézkedések bevezetéséhez.

A WHO és az Európa Tanács ajánlása nyomán számos tagállam kezdte meg betegbiztonsági jelentési rendszerének kiépítését és működtetését. A jelentési rendszerek kialakítása a nemzetközi szervezetek kezdeményezéseinek hatására Európán kívül is megtörtént, így például Ausztráliában, Kanadában, Japánban és az Amerikai Egyesült Államokban is jelentős tapasztalatok gyúltek össze [14-16]. 2014-ben az Európai Bizottság Patient Safety and Quality of Care munkacsoportja összefogásában megjelentetett egy tanulmányt az Európában múködő jelentési rendszerek legfontosabb jellemzőiról és az ezzel kapcsolatos ajánlásokról. Ezek a jelentési rendszerek felépítéséhez, a jelentéshez és a jelentésekből való tanuláshoz szükséges kultúrához, a jelentési rendszerek legfontosabb egységeihez, a beérkező adatok elemzéséhez és a technikai követelményekhez kapcsolódnak. A tanulmány 20 tagország jelentési rendszerét összegzi katalógusszerúen, és mutatja be ôket az előbbi szempontok alapján. A dolgozat fóbb megállapításai alapján a jelenleg múködő rendszerek nagy különbözőségeket mutatnak, ennek ellenére a 2009-ben megjelent ajánlás teljesítését elősegítő javaslatok megfogalmazása a már rendelkezésre álló tapasztalatok alapján lehetségessé és időszerúvé vált [17].

A külföldi jelentési rendszerek bármely esemény jelentésére alkalmas általános jelentési lapokat alkalmaznak. A jelentési lapokon szabad szöveggel történő eseményleírások segítségével lehet a jelentendő eseményeket ismertetni. A szabad szöveges jelentési lapok alkalmazása számos problémát vethet fel. Elemzések szerint nyílt kér- 
désekre adott szöveges leírások nem tartalmazzák az események szisztematikus elemzéséhez nélkülözhetetlen adattartalmat, akadályozva ezzel a jelentési rendszerek valódi céljának teljesülését [15]. Ahhoz, hogy a szabad szöveges jelentések elegendő adatot tartalmazzanak a kiváltó okokról és a hozzá járuló tényezőkről, a jelentőknek megfelelő háttérismeretekkel kell rendelkezniük az elemzésekhez szükséges szempontokról, amely sok esetben nem teljesül.

Felismerve a jelentések minőségének és megfelelő adattartalmának kulcsfontosságú szerepét a hasznosulás szempontjából, a WHO elindította a tanulórendszerek fejlesztésére irányuló úgynevezett MIM (Minimal Information Model for Patient Safety Incident Reporting) projektjét. A projekt célja, hogy meghatározza azt a minimális adatmodellt, amelynek segítségével a nemkívánatos eseményekkel kapcsolatosan gyújtött adatokból megvalósítható a szervezeti tanulás. Ez a projekt elősegítheti a jelentési rendszerek egységesítését, így lehetővé téve a széles körü, nemzetközi adatelemzést és tapasztalatcserét [18].

Thomas és munkatársainak 2011-ben megjelent tanulmánya azt javasolja, hogy a minőségfejlesztéshez jól használható elemzések készítéséhez célszerú a mennyiség helyett a minőségre összpontosítani, és egy-egy célzott incidenstípushoz kapcsolódóan a mélyebb adattartalomra törekedni [15]. A hazai fejlesztések - ezen tanulságok közlése előtt - már 2006-ban ezzel az innovatív megközelítéssel indultak, általános adatlapok helyett olyan eseményspecifikus adatlapokat fejlesztve, amelyek a 2014-2015-ös MIM-fejlesztésben ajánlott adatkört is rögzítik.

Az eseményspecifikus jelentési lapoknak a megfelelő, tervezhető információtartalmon túli előnye, hogy mind az adatlapok kitöltése, mind az adatlapok statisztikai feldolgozása, elemzésre való előkészítése kevesebb időt és erőforrást igényel. Egy nemkívánatos eseménytípus jelentése zárt kérdések és előre meghatározott válaszlehetőségek segítségével nem igényel hosszú időt, a tapasztalatok szerint az adatlapok kitöltése megfelelő gyakorlat esetén körülbelül 5 percet vesz igénybe. Az egyes eseménytípusok hátterében álló specifikus okok és hozzá járuló tényezők adatlapokon történő feltüntetése irányítja a munkatársak gondolkodását, az eseményekkel kapcsolatos faktorok előidejü jelenlétének megértését segítve. Az adatlapok ezért önmagukban is előmozdíthatják az intézményi gyakorlat és múködés biztonságosabbá tételét a rajtuk szereplő tényezők saját környezetben való végiggondolásával.

A jelentési rendszerek múködésének, a jelentési hajlandóság fenntartásának fontos tényezője a jelentések megfelelő időben történő feldolgozása és az időben történő, rendszeres és kellő részletességű visszajelzés [17, 19]. Késői visszajelzések esetén előfordulhat, hogy az elemzések visszaérkezéséig a jelentő intézményben számos feltétel, így az eseményekhez vezető okok jellege, összetétele is megváltozik, ami gátolja a következtetések levonását és a fejlesztések elvégzését. A nem kellő részletességú visszajelzés szintén gátja lehet a valódi okok megtalálásának és az eredményes megelőző intézkedések meghozatalának. A hazai jelentési rendszer eseményspecifikus adatlapjai lehetővé teszik az azonnali visszajelzést az intézmények számára: a jelentő személy jogosultsági szintjétől függően azonnal láthatja a saját osztályos/intézményi adatait az országos aggregált adatokkal való összehasonlításban. A NEVES rendszer előre definiált statisztikái és rövid magyarázatok segítik az eredmények megfelelő értelmezését a hasonló elemzésekben járatlan és leterhelt munkatársak számára. Az informatikai és szakmai fejlesztés eredményeképpen a NEVES szoftver felhasználóbarát, személyre szabható felületet kapott, amely segíti a különböző felhasználói igények kielégítését. A program iránti érdeklődést mutatja, hogy az új felület indítása után egy hónap alatt megkétszereződött a NEVES jelentési rendszerhez kapcsolódó intézmények száma.

A jelentések száma szoros összefüggést mutat a szervezeti kultúrával [19]. A jelentési rendszerek a betegbiztonságot támogató szervezeti kultúra megléte esetén múködnek jól, ami szankcióktól való félelem nélkül teremt lehetőséget a nemkívánatos események megbeszélésére. A hazai NEVES program nemcsak a jelentési rendszer múködtetését vállalta fel, hanem egy komplex betegbiztonsági program részeként, a 2008 decemberében indult NEVES Betegbiztonsági Fórum segítségével a program által képviselt értékek, tudás és tapasztalat továbbadását, széles körű terjesztését is. A fórum a meghívott szakértők és irányított beszélgetések segítségével lehetőséget biztosít a közvetlen tapasztalatcserére, a jó gyakorlatok, új módszerek elméleti és gyakorlati megismertetésére és elterjedésük elősegítésére. Segítségével formálódik a résztvevők közös tudása, gondolkodásmódja, egységessé válik fogalomhasználata. A fórum eddigi 34 ülésének emlékeztetője, illetve az elhangzott előadások anyaga tematikus, kereshető formába rendezve elérhető a http://info.nevesforum.hu/ honlapon. A program képviselőinek szándéka szerint a rendszeres konzultációk, az internetes megjelenés, a képzések, tudományos konferenciákon való részvétel mind hozzájárulnak ahhoz, hogy folyamatosan fejlődhessen a betegbiztonság az egészségügyi szolgáltatások során, és kialakuljon, majd megszilárduljon az ehhez szükséges szervezeti kultúra.

A NEVES jelentési felület által előállított statisztikai eredmények felhasználása során fontos szem előtt tartani, hogy az adatok csak a jelentett esetek vonatkozásában értelmezhetők és értékelhetők. További felhasználói adatgyuujtés végzésével azonban osztályra, intézményre is vonatkoztathatóvá válhatnak a statisztikák. Javasoljuk, hogy néhány hetes adatgyưjtést követően az intézmények végezzenek elemzéseket, oki kutatásokat és ezeken alapuló intézkedési, beavatkozási terveket dolgozzanak ki. A bevezetett intézkedések hatásának lemérése ismételt adatgyưjtés és elemzés végzésével lehetséges. A hatá- 
sok követéséhez, a meghozott intézkedések eredményességének megítéléséhez jó lehetőséget ad a NEVES szoftver trendkövető funkciója, amelynek segítségével egyszerüen, két vagy több időszak feldolgozott eredményeit kaphatjuk meg. Amennyiben egy intézkedés bevezetése után az intézeti szintű adatokban az oki struktúra változása látható, abban az esetben következtethetünk a bevezetett intézkedés kívánt, de az esetleg előre nem jelezhető, nem szándékolt hatásaira is.

A bemutatott egyedi és korszerú megoldások mellett a NEVES program fejlesztésének továbblépési irányai is jól azonosíthatók a hazai tapasztalatok és a nemzetközi ajánlások alapján [17]. Az adatlapok további bővítése során tervezzük egy általános adatlap kifejlesztését, amely további specifikus ürlapok témaválasztásához szolgáltathat értékes információt. Az általános adatlapon ismétlődően jelentett incidenstípusokból a későbbiekben a már meglévőkhöz hasonló szerkezetú témaspecifikus adatlap szerkeszthető.

A jelentésekből való tanulás előmozdítására az országos adatok szakértői feldolgozásából származó tanulságok megosztását kívánjuk erősíteni publikációkkal, elemzések honlapunkon való közzétételével. A NEVES-adatok értelmezéséhez szükséges tudás megszerzésének lehetővé tételére Betegbiztonsági Tanszéki Csoportunk több oktatási programot fejleszt és múködtet, így a témában e-learning tananyagot fejlesztettünk, több rövid programot tartottunk és hirdetünk, rendszeresen oktatunk a graduális és posztgraduális képzésben, valamint a jövőben elismert végzettséget nyújtó program kidolgozását és indítását tervezzük.

A jelentések duplikációinak elkerülése érdekében a gyógyszereléssel összefüggő nem várt események és a hazai farmakovigilancia rendszer összekapcsolását tartanánk célszerünek. A rendszerek összekapcsolását a mellékhatás fogalmának nemzetközi kiterjesztése teszi szükségessé, ami szerint mellékhatásnak minősülnek a gyógyszerek szokásos adagolása során a forgalomba hozatali engedély szerinti alkalmazásból eredő káros és nem kívánt hatásokon kívül a gyógyszerelési hibából, valamint a forgalomba hozatali engedélyben nem szereplő felhasználásból eredő káros, nem kívánt hatások is [6]. Ez a definícióváltozás nemcsak hazánkban, hanem minden gyógyszereléssel összefüggő nemkívánatos eseményre vonatkozó jelentést fogadó szervezet számára az eddig függetlenül működő és más célból kialakított betegbiztonsági és farmakovigilanciai jelentési rendszerek összehangolását teszi szülkségessé.

A nemzetközi ajánlások javasolják a betegek, hozzátartozóik számára is a nemkívánatos események jelentési lehetőségének megteremtését. Véleményünk szerint az ilyen laikus jelentések információtartalma a tanulságok levonása szempontjából kevésbé koncentrált, inkább az új témakörök professzionális jelentésekbe való bevonása szempontjából jelenthetnek hozzáadott értéket. A betegek számára történő fejlesztéseket és azok lehetőségét az illetékes szervezetek bevonásával kívánjuk megvizsgálni a közeljövőben.

A fejlesztés eredményeként létrejött, egyedi megoldásai miatt a nemzetközi érdeklődésre is számot tartó NEVES szoftver, illetve program egyre szélesebb körben válik ismertté. Bízunk benne, hogy mind több egészségügyi ellátó ismeri fel a program adta lehetőségeket és tanulási potenciált, és elkezdi használni ezt az ingyenesen elérhető, a betegbiztonság fejlesztéséhez egyedülálló segítséget, amely megfelelő lehetőség és eszköz a most megjelent jogszabályi kötelezettségek teljesítésére is.

Anyagi támogatás: A szerzők a közlemény megírásáért és a közlemény alapját képező ismeretek összegyưjtéséért, összeállításáért anyagi támogatásban nem részesültek.

Szerzői munkamegosztás: L. J., S. V., S. C.: Irodalomkutatás, információk szintetizálása, a kézirat szövegezése, ábrák, táblázatok szerkesztése. K. L., B. É.: Szakmai lektorálás, a kézirat szövegének véglegesítése.

Érdekeltségek: A szerzők a NEVES jelentési rendszer kialakításának és fejlesztésének aktív résztvevői.

\section{Köszönetnyilvánítás}

Ezúton fejezzük ki köszönetünket Dr. Boros Erzsébetnek és Minya Tündének a NEVES adatlapok kialakításában való aktív részvételükért, és az ezekhez kapcsolódó szakmai munkájukért, továbbá $D r$. Freisinger Ádámnak, Békéssy Lászlónak és Dr. Szarvas Gábornak az informatikai felület tervezéséhez nyújtott ötleteikért és annak megvalósításáért.

\section{Irodalom}

[1] Word Alliance for Patient Safety: Summary of evidence on patient safety: implication for research. Word Health Organization, Geneva, 2008. http://www.who.int/patientsafety/information_ centre/20080523_Summary_of_the_evidence_on_patient_safety.pdf

[2] De Vries, E. N., Ramrattan, M. A., Smorenburg, S. M., et al.: The incidence and nature of in-hospital adverse events: a systematic review. Qual. Saf. Health Care, 2008, 17(3), 216-223.

[3] Belicza, É., Kullmann, L.: Increasing safety of hospital care possibilities and the first national experiences. [A kórházi ellátás biztonságának növelése - lehetőségek és az első hazai tapasztalatok.] Kórház, 2010, 17(1-2), 8-10. [Hungarian]

[4] WHO draft guidelines for adverse event reporting and learning systems. World Health Organization, Geneva, 2005.

[5] Council Recommendation of 9 June 2009 on patient safety, including the prevention and control of healthcare associated infections. 2009/C 151/01. http://eur-lex.europa.eu/LexUriServ/LexUriServ.do?uri=OJ:C:2009:151:0001:0006:HU:PDF

[6] Order 15/2012 (VIII. 22.) of the Ministry of Human Resorces on pharmacovigilance of medicaments used in human. [Az emberi erőforrások minisztere $15 / 2012$. (VIII. 22.) EMMI rendelete az emberi alkalmazásra kerülő gyógyszerek farmakovigilanciájáról.] http://www.ett.hu/tukeb/emmi_15_2012.pdf [Hungarian]

[7] Order 20/2009 of the Ministry of Health on the prevention of infections related to health care attendance and on minimum re- 
quirements and supervison of these activities. [20/2009. (VI. 18.) EüM rendelet az egészségügyi ellátással összefüggó fertőzések megelőzéséról, e tevékenységek szakmai minimumfeltételeiről és felügyeletéről.] http://net.jogtar.hu/jr/gen/ hjegy_doc.cgi?docid=A0900020.EUM [Hungarian]

[8] Act CLIV of the year 1997 on health care. [1997. évi CLIV. törvény az egészségügyrőll.] http://net.jogtar.hu/jr/gen/hjegy_doc.cgi?docid=99700154.TV [Hungarian]

[9] Benn, J., Koutantji, M., Wallace, L., et al.: Feedback from incident reporting: information and action to improve patient safety. Qual. Saf. Health Care, 2009, 18(1), 11-21.

[10] Belicza, É., Kullmann, L.: Realization of the NEVES (adverse events) Hungarian patient safety programme. [NEVES (nem várt események) betegbiztonsági program hazai megvalósítása.] Kórház, 2008, 15(3), 32-35. [Hungarian]

[11] Lám, J., Belicza, É.: Issues of introducing internal reporting systems suitable for signalling adverse events. [Nem várt események jelzésére alkalmas belső jelentési rendszerek bevezetésének kérdései.] Kórház, 2010, 17(1-2), 10-13. [Hungarian]

[12] Neily, J., Ogrinc, G., Mills, P., et al.: Using aggregate root cause analysis to improve patient safety. J. Comm. J. Qual. Saf., 2003, $29(8), 434-439$.

[13] Recommendation on action following a serious adverse event occurred and discovered in the same Health Care Organisation. [Ajánlás adott intézményben kialakult és ott észlelt, súlyos kimenetelú nemkívánatos eseményt követő eljárásra vonatkozóan. NEKED: Nemkívánatos Események Kezelésére vonat- kozó EljárásrenD.] http://semmelweis.hu/emk/files/2012/ 02/neked_ajanlas_final.pdf [Hungarian]

[14] Shojania, K. G.: The frustrating case of incident-reporting systems. Qual. Saf. Health Care, 2008, 17(6), 400-402.

[15] Thomas, M. J., Schultz, T. J., Hannaford, N., et al.: Mapping the limits of safety reporting systems in health care - what lessons can we actually learn? Med. J. Aust., 2011, 194(12), 635-639.

[16] Nakajima, K., Kurata, ., Takeda, H.: A web-based incident reporting system and multidisciplinary collaborative projects for patient safety in a Japanese hospital. Qual. Saf. Health Care, $2005,14(2), 123-129$.

[17] Reporting and learning subgroup of the European Commission $P S Q C W G$ : Key finding and recommendations on reporting and learning systems for patient safety incidents across Europe, 2014. http://ec.europa.eu/health/patient_safety/docs/guidelines_ psqcwg_reporting_learningsystems_en.pdf

[18] European Validation of the Minimal Information Model for Patient Safety Incident Reporting and Learning, 2015. http:// www.who.int/patientsafety/implementation/taxonomy/eumim-validation/en/

[19] Mahajan, R. P.: Critical incident reporting and learning. Br. J. Anaesth., 2010, 105(1), 69-75.

(Lám Judit dr., Budapest, Kútvölgyi út 2., 1125 e-mail: lam@emk.sote.hu)

\section{A rendezvények és kongresszusok híranyagának leadása}

a lap megjelenése előtt legalább 40 nappal lehetséges, a 6 hetes nyomdai átfutás miatt. Kérjük megrendelőink szíves megértését.

A híranyagokat a következő címre kérjük: Orvosi Hetilap titkársága: Budai.Edit@akkrt.hu Akadémiai Kiadó Zrt. 